MINTAKAT: Jurnal Arsitektur

Volume 22, Issue 1, 2021, page. 1-14

MINTAKAT: Jurnal Arsitektur

ISSN: 1411-7193 (Print), 2654-4059 (Online)

\title{
TAMAN WISATA EMBUNG PERSEMAIAN KOTA TARAKAN SEBAGAI DISPLAY ECO ART PARK
}

\author{
Ramadhan Noor ${ }^{1 *}$, A. Tutut Subadyo ${ }^{2}$, Nurhamdoko Bonifacius ${ }^{2}$ \\ ${ }^{1}$ Mahasiswa Program Studi Magister Arsitektur, Universitas Merdeka Malang \\ ${ }^{2}$ Dosen Program Studi Magister Arsitektur, Universitas Merdeka Malang \\ *r4m4dh4n_noor@yahoo.com
}

\begin{abstract}
ABSTRAK
Embung Persemaian merupakan tempat di Kota Tarakan yang potensial menjadi destinasi wisata yang memberikan keuntungan ganda, karena fungsinya sebagai cadangan air baku dan tempat rekreasi. Permasalahannya adalah terjadinya paradok dari kedua fungsi tersebut. Oleh karena itu pengintegrasiannya memerlukan penelitian, desain dan pengelolaan yang komprehensif. Penelitian ini bertujuan untuk : (1) mengidentifikasi karakteristik biogeofisiknya; (2) menganalisis dan membuat sintesis dari potensi dan kendalanya; dan (3) menyusun konsep desain taman wisata sebagai display Eco Art park sesuai preferensi dan ekspektasi masyarakat. Metode penelitian yang digunakan adalah metode analisis spasial dan deskriptif serta metode persamaan kuantifikasi potensi visual. Hasil penelitian yang diperoleh adalah: (1) tapak Embung Persemaian secara signifikan memiliki potensi sebagai destinasi wisata baru dimana faktor pendorong dan penariknya adalah keberadaan dua embung, serta apresiasi dan ekspektasi positif dari masyarakat sekitar $\mathrm{k}$; (2) aspek fisik dan biofisik seperti topografi, bentang visual yang berkarakter khas dan aksesibilitasnya yang mudah dan dalam lingkup urban, menjadi potensial dikembangkan sebagai wadah pemeragaan artwork - land art dan ilmu pengetahuan teknologi, serta konservasi lingkungan. Kesimpulannya Embung Persemaian Kota Tarakan berpeluang dikembangkan dengan pendekatan desain ekologis yang ditujukan untuk memberikan efek psychological distraction agar pengguna secara aktif berinteraksi dengan lingkungan.
\end{abstract}

Kata kunci : embung persemaian, ecoart park, taman wisata, kota tarakan

\begin{abstract}
Embung Persemaian is a place in Tarakan City that has the potential to become a tourist destination that provides multiple benefits, because of its function as raw water reserves and recreational areas. The problem is the occurrence of paradox from the two functions. Therefore integration requires comprehensive research, design and management. This study aims to: (1) identify its biogeophysical characteristics; (2) analyze and make a synthesis of potential and constraints; and (3) drawing up the design concept of a tourist park as an eco art park display according to the preferences and expectations of the community. The research method used is a spatial and descriptive analysis method and equation quantitative visual potential methods. The results of the research are: (1) the Embung Persemaian site has potential as a new tourist destination where the driving and pulling factors are the existence of two reservoirs, as well as positive appreciation and expectations from the surrounding community; (2) physical and biophysical aspects such as topography, visual landscapes with distinctive characteristics and accessibility that are easy and within the urban sphere, have the potential to be developed as a forum for
\end{abstract}


artwork re-enactment - land art and technological science, and environmental conservation. In conclusion, Embung Persemaian is likely to be developed with an ecological design approach aimed at providing a psychological distraction effect so that users actively interact with the environment.

Keywords: embung persemaian, ecoart park, tourist park, city of tarakan

\section{PENDAHULUAN}

Salah satu aspek pengembangan dan pembangunan di Kota Tarakan yang sangat prospektif dan merupakan visi dan misi Kota Tarakan adalah pada bidang kepariwisataan (Bappeda Kota Tarakan, 2015; Dinas Kebudayaan Pariwisata Pemuda dan Olah Raga, 2014). Taman Wisata Embung Persemaian Kota Tarakan (TWEP-KT) merupakan salah satu objek wisata yang potensial untuk dikembangkan. Pengembangannya sebagai sarana rekreasi wisata dan sosial ekonomi, diharapkan menjadi suatu kawasan yang hidup (livable) dan membangkitkan aktifitas sosial ekonomi bagi masyarakat setempat. Pengembangan TWEP-KT perlu pengendalian dengan penerapan prinsip perencanaan dan desain dengan konsep, dengan memperhatikan beberapa aspek yang dapat membentuk fungsi tersebut.

Beberapa aspek yang penting untuk dipertimbangkan adalah : keunikan, kespesifikasian kawasan, lingkungan, dampak pengembangan, persoalan yang ada dan yang berpotensi timbul, faktor efisiensi dalam pemanfaatan lahan, dan potensi ekonomi dan aktivitas produktif lainnya, serta kaidah-kaidah pelestarian fungsi lingkungan.

Dengan fungsi utamanya sebagai tempat cadangan air baku, maka keberadaan TWEP-KT yang akan dikembangkan sebagai destinasi wisata memerlukan pertimbangan-pertimbangan yang komprehensif. Dengan perkataan lain, pengembangan TWEP-KT sebagai objek dan destinasi wisata yang menjadi ruang publik mempunyai masalah yang cukup komplek. Pengelolaan TWEP-KT saat ini masih sebatas sebagai cadangan air baku, meskipun fungsi rekreasi atau wisata juga sudah berlangsung, namun masih sebagai kegiatan komplementer. Oleh karena itu langkah kedepan dalam pengembangannya memerlukan pengintegrasian antara fungsi utamanya sebagai tempat dari sumber air baku yang memiliki limitasi- limitasi tertentu dengan pemanfaatannya sebagai objek atau destinasi wisata.

Pengembangan suatu suatu tempat menjadi destinasi wisata, dalam pandangan (A. T Subadyo, 2011; A.T Subadyo \& Poerwoningsih, 2017; A.Tutut Subadyo, Tutuko, \& Jati, 2019), membutuhkan strategi perencanaan yang komprehensif dan terintegrasi, sehingga dapat meminimalkan dampak negatif, baik dari sudut pandang ekologis, ekonomis maupun sosial budaya dan hukum. Menurut Gunn (1994), perencanaan pengembangan pariwisata ditentukan oleh keseimbangan potensi sumberdaya dan jasa yang dimiliki dan permintaan atau minat pengunjung wisata. Komponen penawaran terdiri dari atraksi 
(potensi keindahan alam dan budaya serta bentuk aktivitas wisata), transportasi (aksessibilitas), pelayanan informasi dan akomodasi dan sebagainya. Sedangkan komponen permintaan terdiri dari pasar wisata dan motivasi pengunjung.

Pada dasarnya unsur-unsur lingkungan hidup dapat dikembangkan sebagai objek wisata, bila unsur-unsur lingkungan hidup tersebut dapat dipersiapkan secara baik melalui kemampuan manusia dengan sentuhan teknologinya, serta dapat memenuhi kebutuhan wisatawan (Faradilla, 2013; Yoeti, 1997). Pembangunan kepariwisataan, memerlukan keterpaduan dan kecermatan studi maupun perencanaan agar tidak terjerumus dalam pembangunan prasarana dan wisata dengan mengorbankan objek atau sumberdaya wisatanya sendiri. Selain itu juga perlu memperhatikan kebutuhan wisatawan, dan keterpaduan dalam perencanaan maupun memformulasikan tujuan (Brown \& Gillespie, 1995; Faradilla, 2013; Yoeti, 1997).

Sejalan dengan prinsip-prinsip pembangunan yang berkelanjutan, pengembangan TWEP KT dibatasi sebagai suatu obyek atau destinasi wisata urban berkonsep taman wisata yang menumpukan atas terpenuhinya kriteria taman ekologis yang di dalamnya diekspresikan sejumlah karya-karya seni dengan tetap mengutamakan pertimbangan keberadaan ruang terbuka hijau (RTH) dan sarana rekreasi di kawasan tersebut. Pilihan tipologi taman ekologi yang diisi dengan peraga (display eco art park) pada TWEP-KT ini merupakan ruang publik yang mewadahi sejumlah fasilitas arsitektur bangunan dan lanskap, serta karya seni rupa. Sebagaimana diketahui, eco art park merupakan pengembangan dari ecopark, yang bertujuan meningkatkan interaksi manusia dengan lingkungannya. Ecopark adalah taman keanekaragaman hayati yang di dalamnya terdapat koleksi tanaman ex-situdan in-situ (Astari, 2011). Dalam konsep pengembangannya, ecopark dipadukan dengan karya seni sehingga menjadi Eco-Art Park (Asyar'ri, 2016; Kartika, 2004), yakni sebuah taman terbuka yang dilengkapi dengan berbagai fasilitas, berbagai taman tematik, dan dipercantik dengan adanya karya seni art work. Dalam pengembangan estetikanya sering menampilkan kultivar tanaman ornamental baru sebagai pengisi, dimana karakter tapak dipertahankan elemen mayor dan elemen minornya dengan melindungi, menggubah, dan merubah bentuk alami, serta penciptaan aksentuasi alami (Simonds \& Starke., 2006; A. T Subadyo, 2011).

Pilihan pengembangan TWEP-KT sebagai taman ekologis yang diperkaya dengan peraga seni dan ilmu pengetahuan ini dilandaskan pada permasalahan bagaimana mengintegrasikan potensi dan kendala tapak dari TWEP-KT yang tetap harus berfungsi secara optimal sebagai lokus cadangan air baku. Dengan demikian, TWEP-KT ini menjadi suatu dstinasi wisata yang memberikan pengalaman terpadu antara atraksi ilmu pengetahuan dan teknologi, seni, dan lingkungan alami kepada para pengunjung. 


\section{METODE PENELITIAN}

Metode yang digunakan pada penelitian ini adalah metode analisis spasial dan deskriptif sesuai dengan tahapan kerja yang di kemukakan oleh Booth (1983); Simonds \& Starke., (2006) yang telah dimodifikasi. Pengumpulan data dilakukan dengan menginventarisasi sejumlah aspek dengan pengamatan langsung di lapangan, dengan fokus pada data fisik dan biofisik tapak. Sedangkan data uyang bertalian dengan aspek sosial budaya, pendekatan desain, dan apresiasi seni diperoleh melalui interview beserta penyebaran kuisioner tertutup kepada masyarakat di Kota Tarakan yang dipilih secara random sampling. Kesemua data tersebut dianalisis dengan metode analisis dekriptif dan spatial, sementara untuk analisis kuantitatif dilakukan dengan metode Persamaan Kuantifikasi Potensi Visual (Asyar'ri, 2016) yang formulanya adalah sebagai berikut :

$$
\begin{array}{ll}
\text { a. } & \text { Persepsi dan reaksi }(\mathrm{Pr}) \\
\mathrm{Pr} & =1.47(\mathrm{t})(\mathrm{v}) \\
\mathrm{b} . & \text { Jarak berhenti }(\mathrm{d}) \\
\mathrm{d} & =\mathrm{V}^{2} / 30 \mathrm{f} \\
\text { c. } & \text { Jarak pandang minimum (D) } \\
\mathrm{D} & =\mathrm{Pr}+\mathrm{d} \\
\text { d. } & \text { Tinggi maksimum }(\mathrm{H}) \\
\mathrm{H} & =\tan \mathrm{oxD}
\end{array}
$$

Potensi visual tapak TWEP-KT yang dianalisis meliputi : persepsi dan reaksi, jarak pandang minimum, dan tinggi maksimum objek yang ada di dalam tapak yang bisa menuntun interpretasi pengguna dan menghasilkan persepsi. Selanjutnya secara kuantitatif, dihitung daya dukung dari sumber daya TWEP-KT yang akan dikembangkan untuk tujuan dan fungsinya sebagai ruang display eco art park.

\section{HASIL PENELITIAN DAN PEMBAHASAN}

Tapak TWEP-KT memiliki potensi untuk dieksplorasi, yakni bentuk kontur yang bervariasi dan badan air embung sebagai pemandangan/view potensial dan menjadi mayor space dengan daya tarik tersendiri. Pepohonan yang asri pada tapak dimaksimalkan sebagai daya tarik untuk dijadikan atraksi yang menarik.
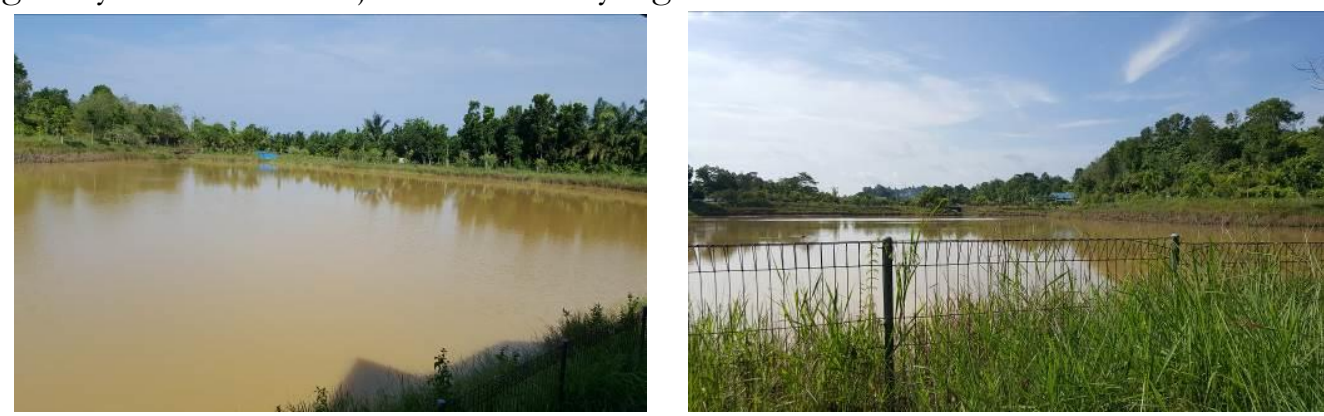

Gambar 1. Good View Pada Tapak Berupa Badan Air Yang Menjadi Mayor Space Sumber : Dokumentasi Peneliti, 2019 
Keadaan topografi pada TWEP-KT yang sebagian bergelombang sangat memberikan keuntungan dalam hal pengolahan dan pemanfaatan keindahan dan sebagai viewing point. Tapak dengan kondisi yang tidak rentan terhadap bahaya longsor dan gerakan tanah, serta memiliki kandungan bahan organik mendukung tapak untuk menampung, mengembangkan, dan membangun fasilitas TWEP-KT sebagai Taman Display Ecoartpark. Eksplorasi visual visibilitas kearah view badan air dan tebing disisi utara tapak dapat dioptimalkan dengan intervensi elemen lanskap serta penggunaan konstruksi dek berbahan organik kayu (Huda, 2014; A.T Subadyo, 2015; A.T Subadyo \& Poerwoningsih, 2017).

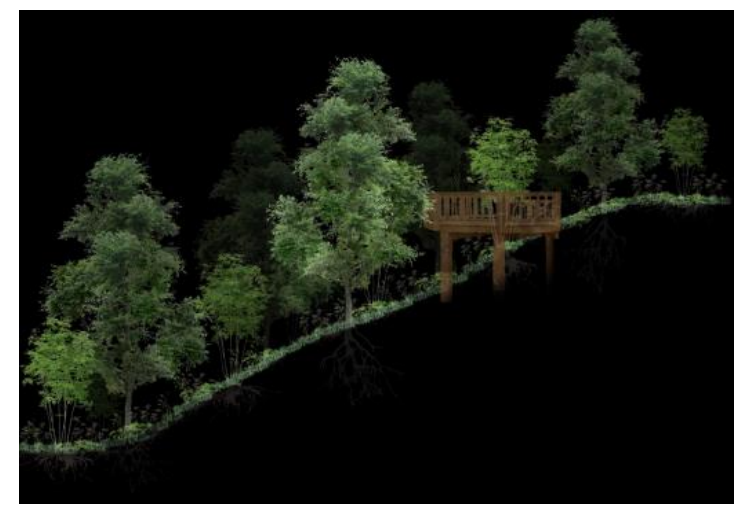

Gambar 2. llustrasi Pemakaian Konstruksi Dek berbahan kayu pada area berkontur curam (Sumber : Huda ZS, 2014 ; Subadyo, 2015, 2017 diolah)

Untuk mengantisipasi terjadinya limpasan air permukaan pada tapak dilakukan pendekatan konservasi pada beberapa titik yang memiliki kemiringan di atas $40^{\circ}$. Teknik konservasi dapat dilakukan dengan pendekatan secara mekanis (pemasangan retaining wall maupun penggunaan gabion) maupun secara ekologis (bio-slope protection dengan memanfaatkan tanaman endemik lokal). Keberadaan saluran drainase pada sisi selatan tapak, menjadi aset yang berperan dalam pengendalian aliran air permukaan sehingga dapat menjaga kondisi tapak dan kawasan TWEP -KT terbebas dari genangan air pada waktu musim penghujan.

Sumber air TWEP-KT berasal dari air tanah, air hujan, air limpasan dari jalan sekitar, dan air sungai yang terletak di timur tapak. Sungai kecil pada tapak berfungsi sebagai destinasi terakhir dari limpasan air permukaan maupun sistem drainase dalam tapak. Permasalahan utamanya adalah tingginya limpasan air permukaan karena kontur cukup curam dan beberapa titik telah mengalami erosi. Untuk mengatasi permasalahan erosi pada tapak TWEP-KT tidak hanya diminimalkan dampaknya, melainkan dipikirkan bagaimana meresapkan air secara maksimal ke dalam tanah sehingga dapat memaksimalkan fungsi ekologisnya. Serta dimaksimalkan sebagai lokasi tadah hujan yang dapat dipanen (rain harvesting) dan ditampung di kolam retensi yang ada. 

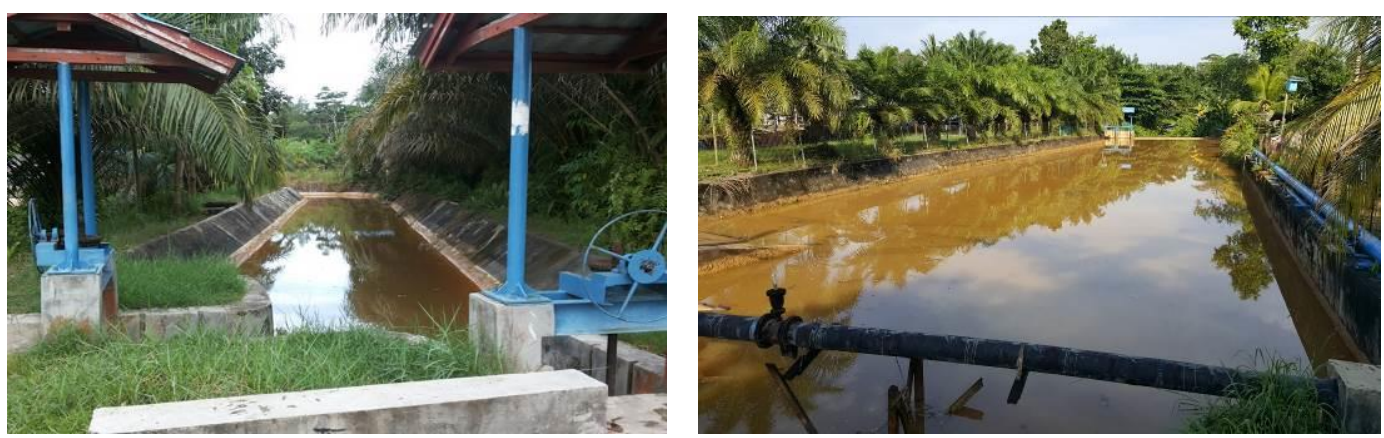

Gambar 3. Saluran Drainase dan Pintu Air Pada TWEP-KT

Sumber : Dokumentasi Peneliti, 2019

Faktor pembatas lain yang sangat penting adalah keberadaan dua buah embung yang selama ini menjadi salah satu cadangan sumber air baku untuk instalasi pengolahan air minum bagi warga Kota Tarakan. Eksistensi dari cadangan air baku ini menjadi determinan utama dalam pengembangan tapak menjadi destinasi wisata. Namun pada sisi lainnya kendala ini juga bisa dipandang sebagai potensi untuk menstimulus terciptanya destinasi wisata yang memanfaatkan air permukaan sebagai latar muka, latar tengah, atau latar belakang dari sejumlah fasilitas yang dikembangkan di dalam tapak dank awasan dengan olahan berbasis water landscape.

Berdasarkan data BMKG Bandara Juata 2018 (suhu udara, kelembaban, curah hujan, kecepatan angin selama satu tahun), maka diperoleh hasil perhitungan indeks kenyamanan manusia dengan Persamaan Kuantifikasi Kenyamanan (Thermal Humudity Index $=0,8 \mathrm{~T}+$ $(\mathrm{RH} \times \mathrm{T}) / 500)$ terhadap rerata suhu dan kelembaban pada lokasi penelitian, dimana hasil nilai THI nya sebesar 24,29. Jika dibandingkan dengan tetapan THI untuk daerah tropis lembab sebesar 27 (Laurie, M., 1986) maka THI pada TWEP-KT masih berada dalam batas kenyamanan. Hal tersebut terpenuhi karena suhu pada TWEP-KT diduga banyak dipengaruhi oleh banyaknya naungan pepohonan.

Keberadaan vegetasi pada tapak TWEP-KT, menghadirkan ruang yang terbentuk oleh susunan vegetasi eksisting bersifat canopied space dengan dominasi pohon dan tanaman penutup tanah serta sedikit variasi semak. TWEP-KT ini cukup teduh dengan kanopi pepohonan yang rapat menutupi area. Canopied space merupakan ruang yang terbentuk dengan penutupan kanopi rapat pada bagian langit-langit dan dengan pandangan terbuka pada bagian dinding atau samping. Ruang yang terbentuk menghadirkan kesejukan bagi user dengan meminimalisir pancaran sinar matahari yang masuk ke dalam ruang (Booth, 1983, Subadyo, 2011; 2018). Pada tapak TWEP-KT dihindari adanya blind spot untuk meminimalisir terjadinya kejahatan, sehingga fungsi canopied space tanpa adanya pandangan yang membatasi ke arah luar tapak sangat sesuai diterapkan pada TWEP-KT. 
Keadaan tapak TWEP-KT yang cukup banyak terdapat vegetasi dan ditumbuhi pohonpohon yang memiliki perakaran yang mendukung konservasi air dan tanah dapat dimanfaatkan sebagai salah satu elemen dalam pengembangannya sebagai display ecoartpark. Tapak TWEP-KT juga memiliki kemiringan dan topografi yang bervariasi juga menjadi aspek penting sebagai faktor limitasi yang harus diperhatikan dalam pengembangan TWEP-KT menjadi destinasi wisata. Dengan kata lain pengembangan TWEP-KT seyogyanya hanya memanfaatkan area yang memiliki kemiringan nol atau datar hingga kemiringan kurang dari $20^{\circ}$ (landai), sedangkan untuk area yang memiliki kontur atau kemiringan agak curam hinga terjal tetap dapat dikembangkan namun dengan melakukan rekayasa tapak dengan teknik yang khusus, seperti penanaman vegetasi pohon penahan erosi, dan pembuatan slope berbasis terasiring.
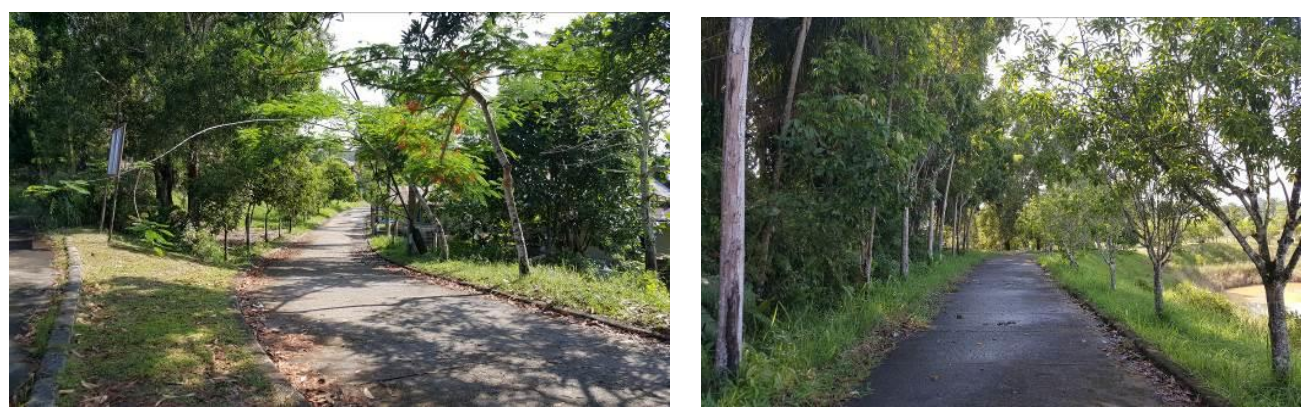

\section{Gambar 4. Koridor Pohon yang telah Terbentuk di dalam tapak}

Sumber : Dokumentasi Peneliti, 2019

Hasil analis visual visibilitas berdasarkan hasil perhitungan kuantifikasi pandangan visual jarak pandang minimum salah satu sequence pada tapak TWEP-KT adalah 38.27 meter dengan lingkaran imajiner untuk pengendara. Sementara itu untuk penikmat dengan berjalan kaki tidak memerlukan pertimbangan jarak pandang minimum akan tetapi lebih difokuskan pada tinggi maksimum dari artwork \& land art yang didesain untuk pengendara sebagai jarak pandang maksmium pejalan kaki. Dengan demikian artwork \& land art yang nantinya teragakan pada sejumlah titik pada tapak TWEP-KT, dapat dilihat secara keseluruhan dari sudut maksimal mata pejalan kaki secara vertikal yaitu $30^{\circ}$.

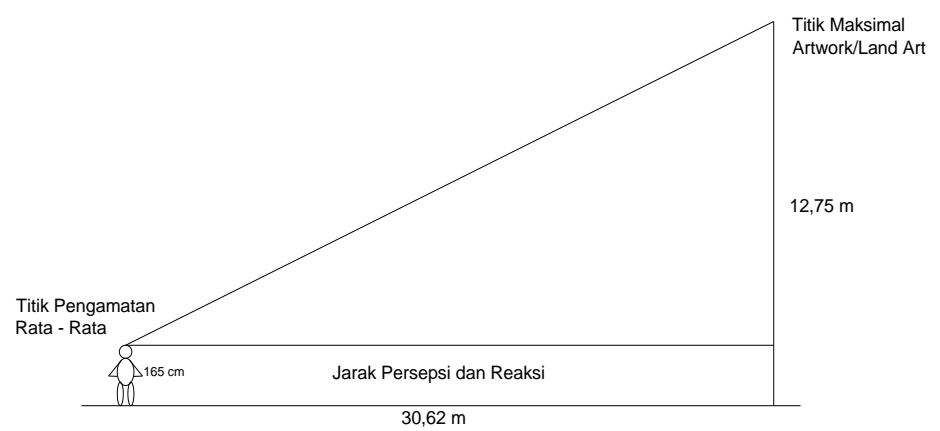

Gambar 5 . Sudut Pandang Visual Secara Vertikal

Sumber : Hasil Perhitungan, 2019 
Hasil perhitungan ketinggian maksimum dari artwork \& land art pada TWEP-KT adalah 12.75 meter. Ketinggian tersebut merupakan ancangan tinggi maksimum yang dapat dilihat secara menyeluruh dari artwork \& land art secara vertikal. Artinya ketinggian maksimum tersebut dapat memberikan proporsi penglihatan yang paling optimal terhadap suatu bidang arsitektural dari desain artwork \& land art yang ideal untuk diperagakan pada TWEP-KT.

\section{Aspek Sosial dan Budaya}

Masyarakat yang berada disekitar kawasan TWEP-KT adalah masyarakat Kelurahan Karang Harapan Kecamatan Tarakan Barat, Kota Tarakan. Diharapkan dengan adanya kegiatan wisata TWEP-KT ini dapat memberikan peluang usaha dan meningkatkan penghasilan, disamping dapat menikmati keunikan objek wisata tersebut. Masyarakat sekitar yang pernah mengujungi TWEP-KT rata-rata dalam satu bulan, satu kali sebanyak $40 \%$, dua kali sebanyak 16,67\%, tiga kali sebanyak 4,44\%, dan lebih dari tiga kali 7,78\%, sedangkan yang tidak pernah mengunjungi lokasi sebanyak 31,11\%. Sebagian besar masyarakat di sekitar TWEP-KT memandang lokasi ini sudah menjadi tempat wisata atau berekreasi.

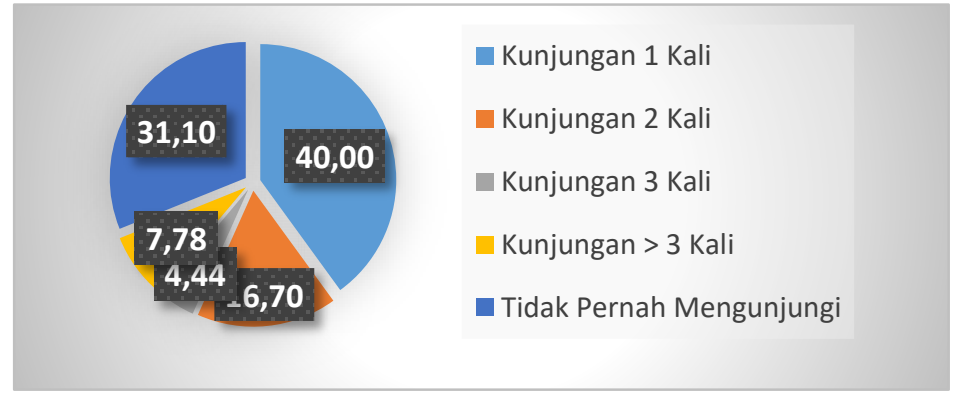

Gambar 6. Kunjungan Masyarakat Sekitar Ke Lokasi TWEP-KT Sumber : Hasil Pengolahan Kuesioner, 2019.

Meskipun objek wisata saat ini hanya berupa "Embung" namun pada kenyataannya pengunjung tidak hanya didominasi masyarakat sekitar. Pengunjung "TWEP-KT" relatif hanya ramai pada akhir pekan. Intensitas pengunjung saat ini tergolong cukup tinggi pada saat pagi dan sore hari dengan aktivitas jogging pada pagi hari dan aktivitas relaksasi seperti duduk-duduk atau sekedar berjalan pada sore hari. Pada sore hari, pengunjung didominasi oleh remaja yang melakukan kegiatan seight seeing dan bermain. 


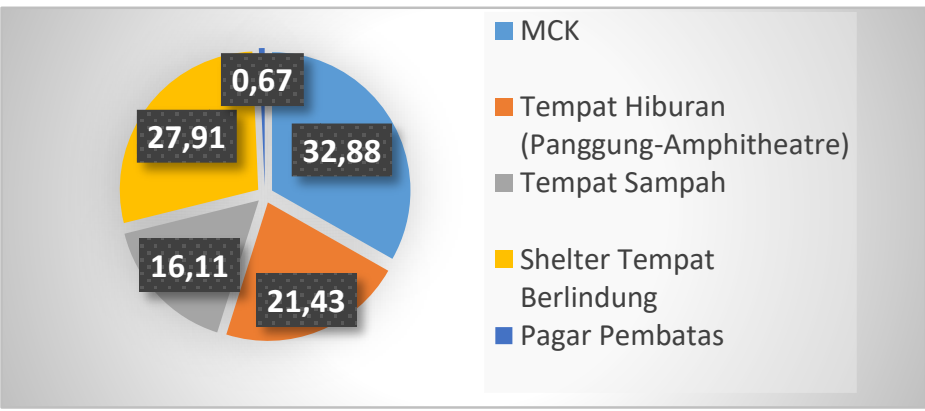

Gambar 7. Fasilitas Yang Perlu Dilengkapi Di Lokasi TWEP-KT Sumber : Hasil Pengolahan Kuesioner, 2019

Sedangkan untuk fasilitas yang perlu diadakan dan ditambah pada TWEP-KT tersaji pada gambar berikut :

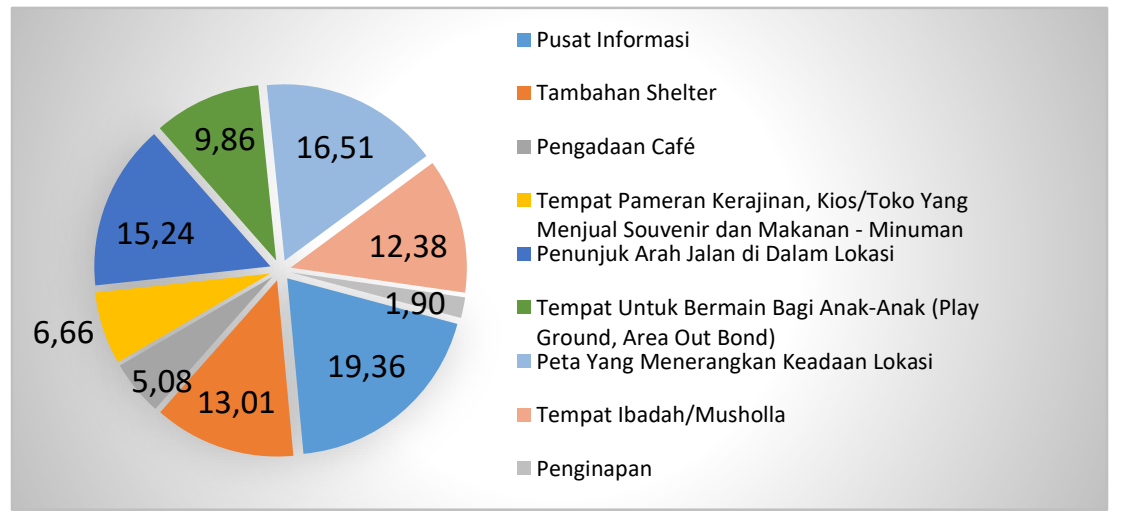

Gambar 8. Fasilitas Yang Perlu Diadakan dan Ditambah Di Lokasi TWEP-KT Sumber : Hasil Pengolahan Kuesioner, 2019

TWEP-KT ini pada akhir pekan dan musim liburan terkadang juga dikunjungi masyarakat di luar kota Tarakan seperti dari Tanjung Selor, Tanjung Palas, Tana Tidung, Bunyu, Nunukan, Malinau, dan lain-lain. Untuk pengembangan TWEP-KT sebagai destinasi wisata, respon masyarakat yang menganggap perlu sebanyak 96,67\% dan yang menganggap tidak perlu sebanyak 3,33\%.

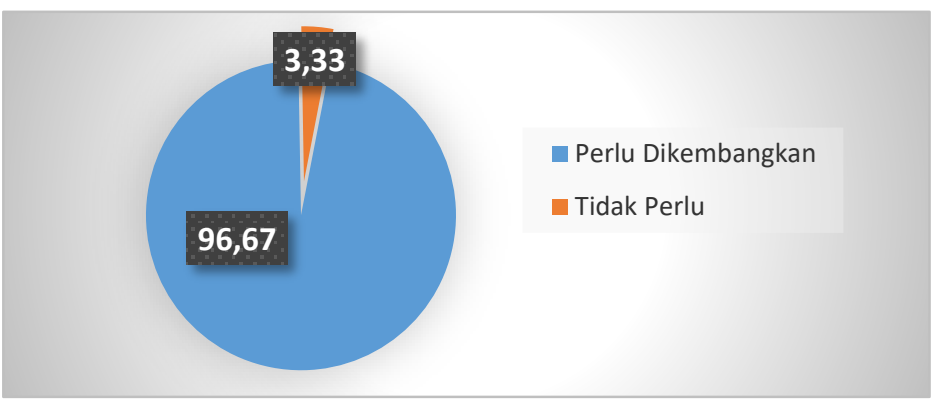

Gambar 9. Respon Masyarakat Terhadap Pengembangan TWEP-KT Sebagai Obyek Wisata Sumber : Hasil Pengolahan Kuesioner, 2019 
Harapan masyarakat sekitar lokasi terhadap pengembangan TWEP-KT ini diantaranya membuka lapangan pekerjaan baru sebanyak 28,45\%, meningkatkan kesejahteraan masyarakat sekitar sebanyak 39,33\%, dan harapan lokasi menjadi terkenal sebanyak $32,22 \%$.

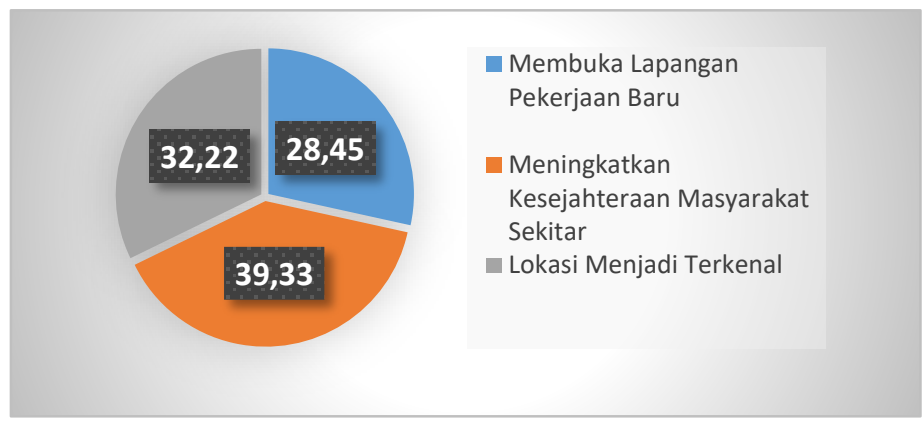

Gambar 10. Harapan Masyarakat Sekitar Terhadap TWEP-KT

Sumber : Hasil Pengolahan Kuesioner, 2019

Berdasarkan hasil kuesioner yang didistribusikan, dapat dilihat permintaan serta ekspektasi masyarakat atas kebutuhan sajian artwork \& land art pada TWEP-KT yang nantinya dapat mereka nikmati, serta memiliki kesesuaian dengan fungsinya sebagai destinasi wisata yang bersifat aktif. Dengan pemahamanan dari hasil analisis visual tersebut, maka karya seni artwork \& land art pada TWEP-KT diperagakan dengan fungsi sebagai media interpretasi imaji berdasarkan pengolahan tapak dan lanskapnya secara psikologis dapat mempengaruhi tafsir kehidupan pengunjungnya.

\section{Pengembangan TWEP-KT}

Dari hasil pembahasan terhadap aspek biofisik, sosial dan budaya di atas dapat dinyatakan bahwa tapak TWEP-KT memiliki potensi dan peluang untuk dikembangkan sebagai objek atau destinasi wisata baru di Kota Tarakan. Sejumlah hal penting yang harus diperhatikan dan dipersyaratkan dalam pengembangan tapaknya sebagai objek/destinasi wisata adalah optimalisasi keberadaan ruang publik, pola dan struktur jalan serta aksisibilitasnya, dan kelengkapan fasilitas dan utilitasnya. Dengan ekspektasi bahwa TWEP-KT adalah sebuah taman display yang akan dipenuhi dengan berbagai karya seni artwoks \& land art, dan menerapkan konsep penataan yang terintegrasi, maka pengembangannya didasarkan pada formulasi konsep ruang, sirkulasi, dan konservasi.

Bertolak dari formulasi konsep ruang (penerimaan, pelayanan, rekreasi, dan ekologi) dan konsep sirkulasi, ragam fungsi, serta hasil studi aktivitas - ruang gerak maka kebutuhan fasilitas dari pengembangan TWEP-KT sebagai destinasi wisata di Kota Tarakan yang difungsikan sebagai peraga karya seni dan ilmu pengetahuan disajikan pada tabel di bawah ini. 
Tabel 1. Fasilitas TWEP-KT

\begin{tabular}{|c|c|c|c|}
\hline No & Jenis Ruang & Sub Ruang & Kebutuhan Fasilitas \\
\hline \multirow[t]{4}{*}{1.} & \multirow{4}{*}{$\begin{array}{l}\text { Penerimaan } \\
\text { (Welcome space) }\end{array}$} & \multirow{4}{*}{$\begin{array}{l}\text { Penerimaan } \\
\text { Introduction Space }\end{array}$} & Entrance Hall \\
\hline & & & Gerbang, Pos Jaga, Ticketing \\
\hline & & & Art Work, Land Art, Signed \\
\hline & & & Plaza \\
\hline \multirow[t]{7}{*}{2.} & \multirow[t]{7}{*}{$\begin{array}{l}\text { Pelayanan (Service } \\
\text { space) }\end{array}$} & \multirow[t]{7}{*}{ Pelayanan } & $\begin{array}{l}\text { Parkir : Mobil, Sepeda Motor, dan Sepeda } \\
\text { Gowes }\end{array}$ \\
\hline & & & Toilet Umum \\
\hline & & & Musholla \\
\hline & & & Kantor Pengelola \\
\hline & & & Gedung Pelayanan Pariwisata \\
\hline & & & Food Center, Kios Mamin \& Cinderamata \\
\hline & & & Art Work, Land Art, Signed \\
\hline \multirow[t]{10}{*}{3.} & \multirow{10}{*}{$\begin{array}{l}\text { Rekreasi } \\
\text { (Recreation space) }\end{array}$} & \multirow{10}{*}{$\begin{array}{l}\text { Ruang Bermain } \\
\text { Anak, Remaja, dan } \\
\text { Dewasa }\end{array}$} & Sarana Bermain Anak \\
\hline & & & Bangku Taman, dan Papan Interpretasi \\
\hline & & & Jalur Refleksi, dan Jalur Pedestrian \\
\hline & & & Coverage Walkway \\
\hline & & & Gazebo, Art \& Antique Gallery \\
\hline & & & $\begin{array}{l}\text { Ruang Peraga Ipteks, Kolam Renang, Arena } \\
\text { Go Car, Bom-bom Car, dan Carousel }\end{array}$ \\
\hline & & & Art Work, Land Art, Signed \\
\hline & & & Amphiteater \\
\hline & & & $\begin{array}{l}\text { Miniatur : Borobudur, Taj Mahal, Pyramida, } \\
\text { Menara Eiffel, Menara Pisa, Coleseum, dan } \\
\text { Tembok Cina }\end{array}$ \\
\hline & & & Sangkar Burung \\
\hline \multirow[t]{3}{*}{4.} & \multirow{3}{*}{$\begin{array}{l}\text { Ekologi } \\
\text { (Ecological space) }\end{array}$} & \multirow{3}{*}{$\begin{array}{l}\text { Embung } \\
\text { RTH Farming }\end{array}$} & Embung \\
\hline & & & Art Work \& Land Art \\
\hline & & & $\begin{array}{l}\text { Taman : Eksotik, Herbal, Organik, Bonsai, } \\
\text { Palem, dan Tanaman Hias. }\end{array}$ \\
\hline
\end{tabular}

Sintesis yang dapat disarikan sebagai implementasi hasil penelitian dan formulasi konsep pengembangannya, disajikan ilustrasi atau gambaran dari Site Plan pengembangan TWEPKT, sebagaimana tersaji pada gambar-gambar berikut : 


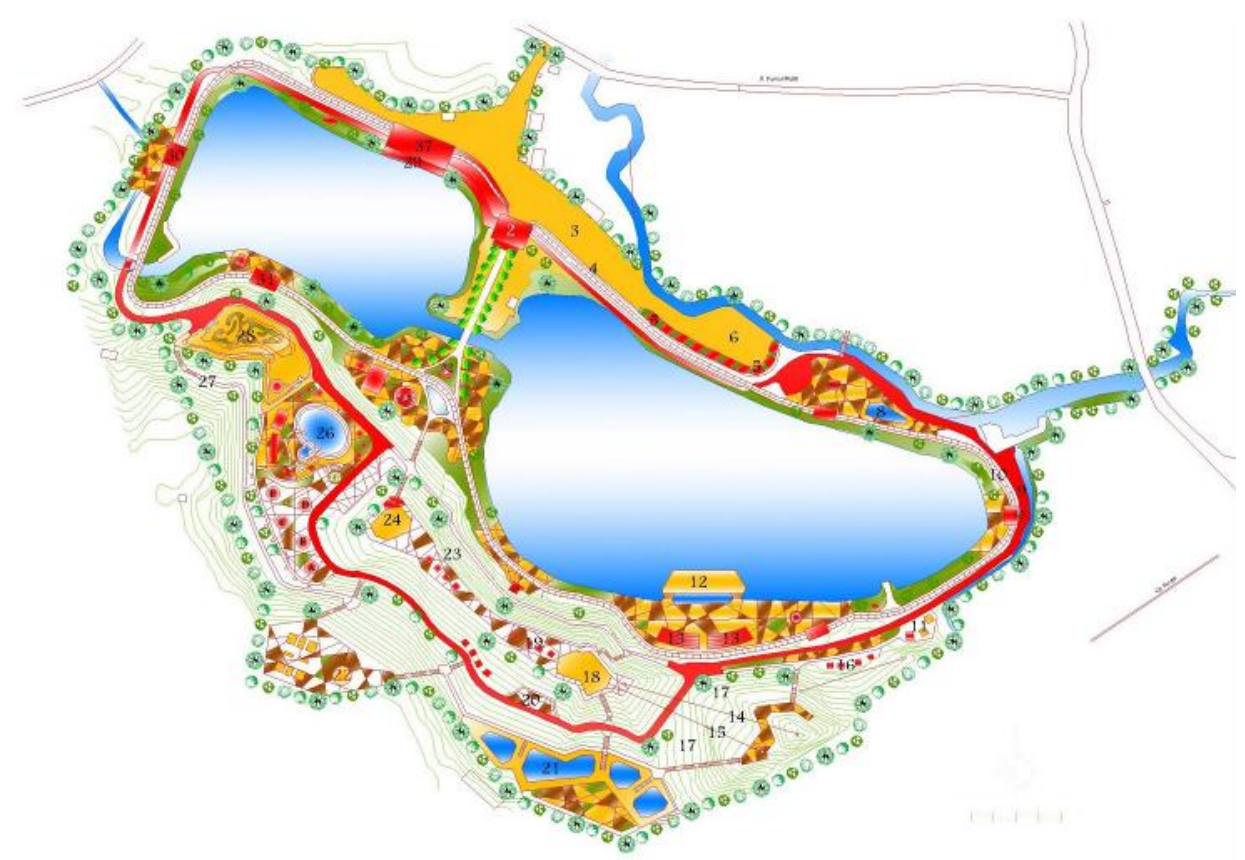

Gambar 11. Site Plan Taman Wisata Embung Persemaian Kota Tarakan

Sumber : Usulan Peneliti, 2019

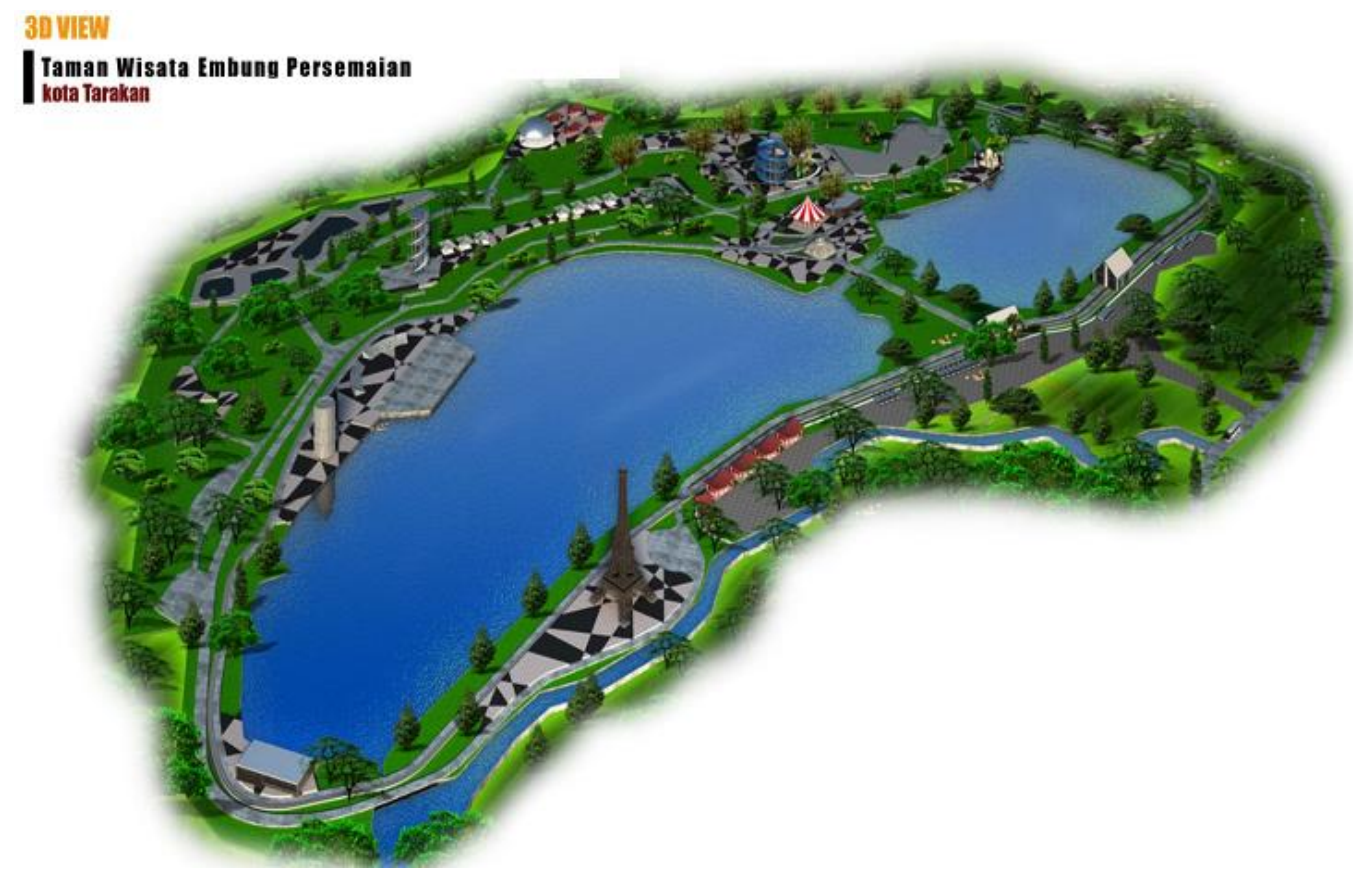

Gambar 12. 3D View 1 Taman Wisata Embung Persemaian Kota Tarakan

Sumber : Usulan Peneliti, 2019 


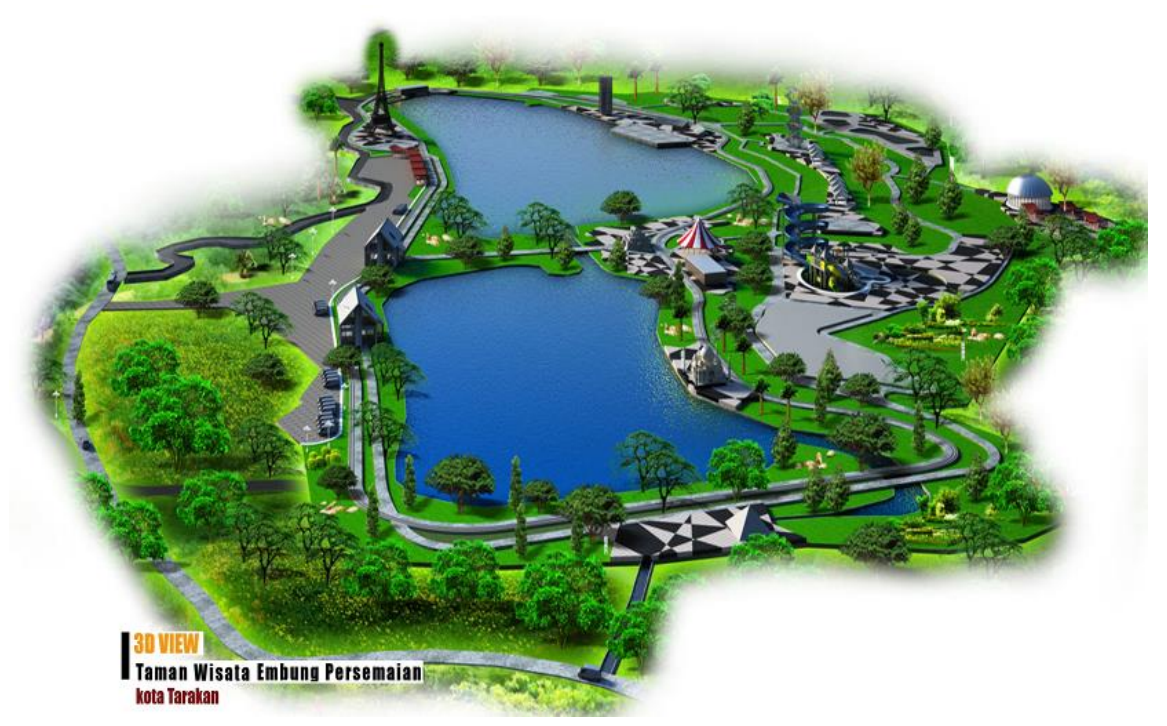

Gambar 13. 3D View 2 Taman Wisata Embung Persemaian Kota Tarakan

Sumber : Usulan Peneliti, 2019

\section{SIMPULAN}

Berdasarkan hasil analisis dan pembahasan sebagaimana diuraikan di atas dapat ditarik kesimpulan, bahwa:

- Tapak Embung Persemaian Kota Tarakan secara signifikan memiliki potensi sebagai destinasi wisata baru dimana faktor pendorong dan penariknya (push and pull factors) adalah keberadaan dua embung serta apresiasi, preferensi dan ekspektasi positif dari masyarakat sekitar tapak. Selain itu aspek fisik dan biofisik dan aksesibilitasnya yang mudah serta masih dalam lingkup urban, menjadi potensi sebagai wadah peragaan artwork dan land art serta peraga ilmu pengetahuan serta konservasi lingkungan.

- Faktor utama yang menjadi pertimbangan dalam pengembangan TWEP-KT adalah fungsinya sebagai cadangan air baku dan sebagai mayor space yang unik. Perlu dikelola secara terintegrasi sehingga tetap terjaga kualitas airnya.

- Peningkatan potensi tapak TWEP-KT sebagai destinasi wisata yang mewadahai peragaan ilmu pengetahuan teknologi, artwokrs dan land art serta elemen-elemen desain tapak lainnya membutuhkan identitas kawasan tersebut, dengan mengeksplorasi bentukan-bentuk irregular/tidak beraturan-minimalis berdasarkan desain ekologis, untuk memberikan efek psychological distraction.

\section{REFERENSI}

Asyar'ri, M. F. (2016). Desain Land Art Ruang Publik YS AWR Kota Pekanbaru. Bogor: IPB.

Bappeda Kota Tarakan. (2015). Rencana Pembangunan Jangka Panjang (RPJP) Kota Tarakan. Kota Tarakan. 
Booth, N. K. (1983). Basic Elemen Of Landscape Architecture Design. New York (USA): Waveland Press Eckbo.

Brown, R., \& Gillespie, T. (1995). Microclimate Landscape Design, Creating Thermal Confort and Energy Efficiency. Canada: John Wiley \& Son.

Dinas Kebudayaan Pariwisata Pemuda dan Olah Raga. (2014). KAK Perencanaan Obyek Wisata Embung Persemaian Kota Tarakan.

Faradilla. (2013). Pengelolaan Landscape Ecoartpark. Sentul Bogor.

Gunn, C. (1994). Tourism Planning : Basic, Concepts, Cases. Washington DC (USA): Taylor \& Francis.

Huda, Z. (2014). Jejaring Pocket Park, Sebagai Ruang Resapan Air Hujan. Bogor.

Kartika, D. (2004). Seni Rupa Modern. Jakarta: Rekayasa Sains.

Simonds, J., \& Starke. (2006). Landscape arcbitecture: A Manual Of Site Planning and Design. New York (USA): Mc Graw Hill Book Co.

Subadyo, A. T. (2011). Lanskap Kultural dan Spaial Desa Pakraman. malang: niversitas Merdeka Malang, Press.

Subadyo, A.T. (2015). Infrastruktur dan Daya Tampung Tapak. malang: Unmer Press.

Subadyo, A.T, \& Poerwoningsih, D. (2017). Design of Integrated Infrastucture Development in Poncokusumo Agropolitan Region Malang Indonesia. Ecology, Environment and Conservation Journal, 23(1), 63-70.

Subadyo, A.Tutut, Tutuko, P., \& Jati, R. M. B. (2019). Implementation Analysis of Green City Concept Malang - Indonesia. Journal International Review for Spatial Planning and Sustainable Development, 7(2), 36-52.

Yoeti, O. (1997). Pengantar Pariwisata. Jakarta: Gramedia. 